Wahida Purnamasari. Kajian Efektifitas Dan Kepuasan Pengguna Website Badan Narkotika 2021

Nasional Kota Kupang.

\title{
KAJIAN EFEKTIFITAS DAN KEPUASAN PENGGUNA WEBSITE BADAN NARKOTIKA NASIONAL KOTA KUPANG
}

\author{
Wahida Purnamasari \\ Program Studi Sistem Informasi Sekolah Tinggi Manajemen Informatika Komputer (STIKOM) Uyelindo \\ Jl. Perintis Kemerdekaan I, Kota Kupang, Nusa Tenggara Timur \\ Email: wahida.purnamasari@gmail.com
}

\begin{abstract}
ABSTRAK
Dalam menunjang program kerja Badan Narkotika Nasional (BNN) Kota Kupang yaitu pencegahan, pemberantasan, penyalahgunaan dan peredaran gelap narkoba (P4GN) maka dibangun sebuah website yang bertujuan untuk memberikan informasi tentang bahaya penyalahgunaan narkoba. Sejak diimplementasikan, website tersebut belum pernah dievaluasi apakah telah mampu mencapai tujuannya sebagai media layanan informasi yang berguna. Oleh karena itu, perlu dilakukan kajian terutama dari segi efektifitas dan segi kepuasan pengguna. Adapun tujuan yang hendak dicapai dari penelitian ini adalah mengkaji efektifitas website berdasarkan pendekatan utility system dan kepuasan pengguna dengan menggunakan metode end user computing satisfaction (EUCS) sehingga dapat diketahui tingkat keberhasilan implementasinya serta memperoleh rekomendasi perbaikan website tersebut. Penelitian dilakukan menyebarkan kuesioner secara daring dengan jumlah sampel sebanyak 110 responden yang merupakan pegawai BNN, relawan dan penggiat BNN serta masyarakat yang mengakses website BNN Kota Kupang. Penentuan sampel dilakukan menggunakan teknik accidental sampling. Hasil dari penelitian adalah rerata interval indeks berdasarkan metode utility system mendapatkan nilai sebesar $78,68 \%$ yang dikategorikan dalam tingkat kelayakan baik, yang berarti responden menilai informasi-informasi yang disajikan pada website BNN efektif. Seilain itu, rerata capaian indikator berdasarkan metode EUCS mendapatkan nilai sebesar $77,22 \%$ dan termasuk dalam kategori tinggi yang berarti pengguna merasa puas menggunakan website BNN Kota Kupang. Hasil penelitian menunjukkan bahwa website BNN Kota Kupang dapat digunakan untuk sebagai media informasi yang efektif dan memuaskan, akan tetapi perlu dilakukan perbaikan dan pengembangan sesuai dengan rekomendasi yang diberikan.
\end{abstract}

\section{Kata Kunci : BNN, efektifitas website, EUCS, kepuasaan pengguna, utility system}

\begin{abstract}
In supporting the work program of the National Narcotics Agency (BNN) of Kupang City, namely prevention, eradication, abuse and illicit drug trafficking, a website was built that aims to provide information about the dangers of drug abuse. Since its implementation, the website has never been evaluated whether it has been able to achieve its goals as a useful information service medium. Therefore, it is necessary to conduct a study, especially in terms of effectiveness and in terms of user satisfaction. The objectives to be achieved from this research are to examine the effectiveness of the website with a utility system approach and user satisfaction using the end user computing satisfaction (EUCS) method so that the level of success of its implementation can be known and obtain recommendations for improving the website. The research was conducted by distributing online questionnaires with a total sample of IIO respondents who were BNN employees, volunteers and BNN activists and the public who accessed the Kupang City BNN website. Determination of the sample is done using accidental sampling technique. The result of the research is the average index interval based on the utility system method gets a value of $78.68 \%$ which is categorized in a good level of feasibility, which means that respondents assess the information presented on the BNN website as effective. In addition, the average indicator achievement based on the EUCS method gets a value of $77.22 \%$ and is included in the high category which means that users are satisfied using the Kupang City BNN website. The results show that the Kupang City BNN website can be used as an effective and satisfying information medium, but it needs to be improved and developed in accordance with the recommendations given.
\end{abstract}

\section{Keywords: BNN, EUCS, user satisfaction, utility system, web effectiveness I. PENDAHULUAN \\ Dalam era digital ini teknologi informasi merupakan bagian dari kehidupan manusia. Teknologi informasi telah dirancang dan dikembangkan sesuai dengan kebutuhan bisnis yang ditujukan untuk efektivitas \\ proses bisnis (Tjiptabudi dan Bernardino, 2020). Peran teknologi informasi dirasakan makin besar karena hampir semua kegiatan bisnis dalam organisasi dapat dilakukan melalui perantara teknologi informasi, salah satunya melalui internet. Internet telah menjadi bagian yang tidak}




\begin{tabular}{l|l|l} 
Jurnal Sains Komputer dan Teknologi Informasi & Page \\
e-issn: 2655-7460. Volume 4 No.1, April 2021 & $35-44$ \\
\hline
\end{tabular}

terpisahkan dari kehidupan manusia di era digital ini. Dengan internet, segala informasi yang diinginkan dapat dengan mudah dan cepat didapatkan, padahal untuk mengelola data dan menghasilkan informasi di semua jenis organisasi bukanlah pekerjaan yang mudah karena memakan waktu, mahal, dan menggunakan banyak sumber daya (Tjiptabudi, et al., 2018).

Salah satu pemanfaatan internet adalah dengan hadirnya website. Website merupakan sebuah sistem dengan informasi yang disajikan dalam bentuk teks, suara, dan lain-lain yang tersimpan dalam sebuah server yang disajikan dalam bentuk hiperteks (Simarmata, 2010). Website memiliki peranan penting bagi sebuah organisasi karena dapat memberikan informasi yang bisa diakses oleh masyarakat luas. Salah satu organisasi yang memanfaatkan website adalah organisasi pemerintahan yaitu Badan Narkotika Nasional.

Badan Narkotika Nasional (BNN) merupakan salah satu organisasi pemerintahan vertikal, yang memiliki 34 (tiga puluh empat) Badan Narkotika Nasional Provinsi (BNNP) dan 173 (seratus tujuh puluh tiga) Badan Narkotika Nasional Kabupaten/Kota (BNNK/Kota), salah satunya yaitu BNN Kota Kupang. Adapun program kerja BNN Kota Kupang yaitu Pencegahan, Pemberantasan dan Penyalahgunaan Peredaran Gelap Narkotika (P4GN).

BNN Kota Kupang telah mengimplementasikan website yang bertujuan memberikan informasi tentang kegiatan BNN Kota Kupang dan juga memberikan informasi tentang bahaya penyalahgunaan narkoba. Sejak diimplementasikan, website tersebut belum pernah dievaluasi apakah telah mampu mencapai tujuannya sebagai media layanan informasi yang berguna. Oleh karena itu, perlu dilakukan kajian terutama dari segi efektifitas dan segi kepuasan pengguna. Adapun tujuan yang hendak dicapai dari penelitian ini adalah mengkaji efektifitas website berdasarkan pendekatan utility system dan kepuasan pengguna dengan menggunakan metode end user computing satisfaction (EUCS) sehingga dapat diketahui tingkat keberhasilan implementasinya serta memperoleh rekomendasi perbaikan website tersebut.

\section{METODE}

\section{I. Metode Pengumpulan Data}

Pengumpulan data yang dilakukan dalam penelitian ini adalah dengan menggunakan kuesioner, observasi dan studi pustaka. Kuesioner disusun berdasarkan pendekatan utility system untuk mengkaji efektifitas website dan metode EUCS untuk mengkaji kepuasan pengguna. Observasi dilakukan secara langsung pada website BNN Kota Kupang sebagai pembanding dengan data yang terkumpul menggunakan kuesioner. Studi pustaka dilakukan dengan mencari literatur pendukung penelitian yang mampu memberikan informasi yang memadai serta membantu mempertegas teori-teori yang ada.

2.2. Tahapan Penelitian
Penelitian ini dilakukan melalui beberapa tahap yang dapat dilihat pada gambar beikut:

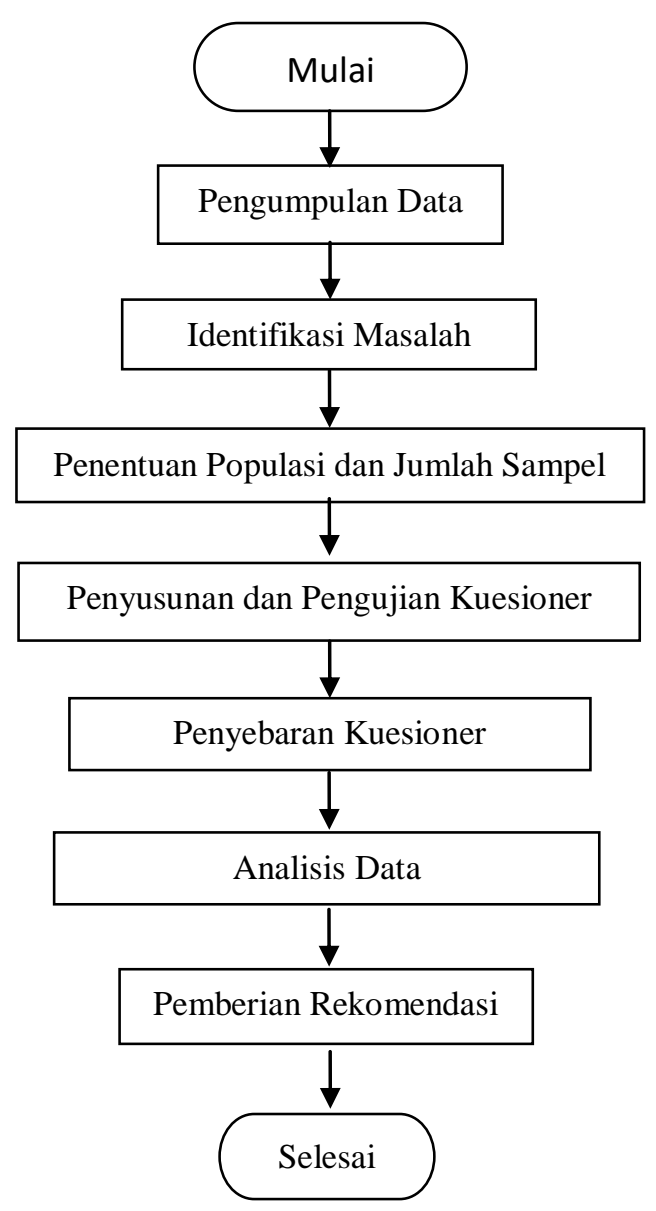

Gambar I. Tahapan penelitian

Populasi dalam penelitian ini adalah user (pengguna akhir) yang mengakses website BNN Kota Kupang, sehingga populasi dianggap tidak diketahui pasti. Maka untuk penentuan jumlah sampel mengacu pada pernyataan Hair, et.al (2010) bahwa banyaknya sampel sebagai responden harus disesuaikan dengan banyaknya variabel yang akan digunakan pada kuesioner, dengan asumsi $\mathrm{n} \times 5$ observed variable sampai dengan $\mathrm{n} \times 10$ observed variable. Pada penelitian ini terdapat II variabel sehingga berdasarkan perhitungan ukuran sampel, jumlah sampel pada penelitian adalah 110 responden yang ditentukan dengan teknik accidental sampling. Accidental sampling, yaitu teknik penentuan sampel berdasarkan kebetulan, yaitu siapa saja yang secara kebetulan atau insidental bertemu dengan peneliti dapat digunakan sebagai sampel, bila dipandang orang yang kebetulan ditemukan cocok sebagai sumber data (Sugiyono, 2017).

Kuesioner disusun mengacu pada 6 (enam) variabel pada pendekatan utility system dan 5 (lima) variabel pada metode EUCS. Utility System adalah pendekatan untuk mengevaluasi implementasi sistem 
Wahida Purnamasari. Kajian Efektifitas Dan Kepuasan Pengguna Website Badan Narkotika 2021 Nasional Kota Kupang.

informasi yang pertama kali diusulkan oleh Kendall dan Kendall (dalam Falahah dan Rijayana, 20II), yang meninjau keberhasilan implementasi sistem dari enam sudut pandang yaitu possession (kepemilikan), form (bentuk), place (tempat), time (waktu), actualization (sebenarnya), dan goal (tujuan). Sedangkan metode evaluasi EUCS dikembangkan oleh Doll \& Torkzadeh pada tahun 1998 dan metode ini menekankan kepuasan (satisfaction) pengguna akhir terhadap aspek teknologi dengan menilai konten, keakuratan, format, ketepatan waktu, dan kemudahan penggunaan dari sistem (Rosalina, 2017). Dimensi EUCS seperti pada gambar di bawah ini:

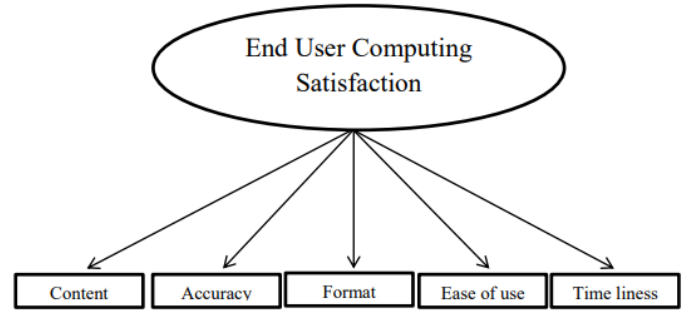

Gambar 2. Metode EUCS

Kuesioner kemudian diuji validitas dan reliabiltasnya dengan menggunakan software SPSS untuk mengetahui tingkat kebenaran atau kesahihan kuesioner serta untuk menunjukkan sejauh mana hasil pengukuran relatif konsisten apabila alat ukur digunakan berulang kali. Kusioner yang telah valid dan reliabel kemudian disebarkan kepada responden secara daring.

Analisis data dilakukan dengan analisis kuantitatif dengan menggunakan skala pengukuran likert Adapun rumus yang digunakan pada pendekatan utility system yaitu menghitung nilai skor pada tiap kriteria, hasil dari penilaian responden:

$$
\text { Nilai skor }=\mathrm{T} \times \mathrm{Pn}
$$

Keterangan:

$\mathrm{T}=$ Total jumlah responden yg memilih

$\mathrm{Pn}=$ Pilihan angka skor likert

Menghitung nilai deskriptif setiap aspek dengan rumus:

$$
\text { Nilai Deskriptif }=\frac{\text { Jumlah Skor }}{\text { Jumlah Responden }}
$$

Menghitung nilai quality factor dalam bentuk persentase (\%) dengan menggunakan persamaan rumus interval index (\%):

$$
\text { Interval Index }=\frac{\text { Total Skor }}{\mathrm{Y}} \times 100 \%
$$

Kemudian, persentase nilai kelayakan dikategorikan seperti pada tabel berikut:

Tabel I. Persentase nilai kelayakan

\begin{tabular}{cc}
\hline Persentase & Kategori \\
\hline $0 \%-19,99 \%$ & Sangat (Tidak Setuju/ Buruk/ \\
Kurang Sekali) \\
$20 \%-39,99 \%$ & Tidak Setuju/ Kurang Baik \\
\hline
\end{tabular}

$$
\begin{array}{cc}
40 \%-59,99 \% & \text { Cukup/ Netral } \\
60 \%-79,99 \% & \text { Setuju/ Baik/ Suka } \\
80 \%-100 \% & \text { Sangat (Setuju/ Baik/ Suka) }
\end{array}
$$

Rumus yang digunakan pada metode EUCS adalah:

$$
\mathrm{Cl}=\frac{\mathrm{JR}}{\mathrm{SI}} \times 100 \%
$$

Keterangan :

$\mathrm{Cl}$ : Capaian indikator

JR: Jumlah jawaban responden

SI : Skor ideal (skor tertinggi dikalikan dengan jumlah responden)

Hasil perhitungan akan dikategorikan dengan pembobotan seperti berikut:

Tabel 2. Kategori capaian indikator

\begin{tabular}{cc}
\hline Persentase & Kategori \\
\hline $0 \%-20 \%$ & Tidak Baik/ Sangat Rendah \\
$21 \%-40 \%$ & Kurang Baik/ Rendah \\
$41 \%-60 \%$ & Cukup Baik/ Cukup Tinggi \\
$61 \%-80 \%$ & Baik/ Tinggi \\
$81 \%-100 \%$ & Sangat Baik/ Sangat Tiggi \\
\hline
\end{tabular}

\section{Hasil Dan Pembahasan}

\section{I. Hasil Uji Kuesioner}

Uji kuesioner pada penelitian ini menggunakan pengujian validitas dan reliabilitas.

Uji validitas dilakukan dengan bantuan SPSS menggunakan uji dua sisi dengan taraf signifikansi sebesar 0,05 . Hasil uji validitas untuk 6 (enam) variabel berdasarkan pendekatan utility system dapat dilihat pada tabel berikut:

Tabel 3. Hasil uji validitas kuesioner utility system

\begin{tabular}{cccc}
\hline Variabel & Item & $\begin{array}{c}\text { Nilai Sig. } \\
\text { (2-tailed) }\end{array}$ & Ket. \\
\hline Possesion (PO) & POI & 0,000 & Valid \\
& PO2 & 0,000 & Valid \\
Goal (G) & GI & 0,000 & Valid \\
& G2 & 0,000 & Valid \\
& G3 & 0,000 & Valid \\
Place ( (6) & PI & 0,000 & Valid \\
& P2 & 0,000 & Valid \\
Form (F) & P3 & 0,000 & Valid \\
& FI & 0,000 & Valid \\
& F2 & 0,000 & Valid \\
Time (T) & F3 & 0,000 & Valid \\
& TI & 0,000 & Valid \\
Actualization (A) & T2 & 0,000 & Valid \\
& AI & 0,000 & Valid \\
& A2 & 0,000 & Valid \\
\hline
\end{tabular}

Berdasarkan hasil uji validitas terhadap item pernyatan pada utility system, dapat dilihat bahwa seluruh pernyataan dinyatakan valid karena memiliki nilai Sig.(2tailed) lebih kecil dari nilai $\alpha$ sebesar 0,05 . 
Adapun hasil uji validitas untuk pernyataan kuesioner berdasarkan metode EUCS dapat dilihat pada tabel berikut:

Tabel 4. Hasil uji validitas kuesioner EUCS

\begin{tabular}{cccc}
\hline Variabel & Item & $\begin{array}{c}\text { Nilai Sig. } \\
\text { (2-tailed) }\end{array}$ & Ket. \\
\hline Content (C) & Cl & 0,000 & Valid \\
& C2 & 0,000 & Valid \\
& C3 & 0,000 & Valid \\
Accuracy (A) & C4 & 0,000 & Valid \\
& AI & 0,000 & Valid \\
Format (F) & A2 & 0,000 & Valid \\
& FI & 0,000 & Valid \\
Timeliness (T) & F2 & 0,000 & Valid \\
& TI & 0,000 & Valid \\
Ease of use (E) & T2 & 0,000 & Valid \\
& EI & 0,000 & Valid \\
& E2 & 0,000 & Valid \\
\hline
\end{tabular}

Hasil uji validitas terhadap item pernyataan pada kuesioner dengan metode EUCS identik dengan kuesioner utility system yang telah dibahas sebelumnya. Semua pernyataan dinyatakan valid karena memiliki nilai Sig.(2-tailed) lebih kecil dari nilai $\alpha$ sebesar 0,05 .

Hasil uji reliabilitas yang diperoleh menunjukkan bahwa instrumen yang digunakan memenuhi syarat dan dianggap sangat reliabel karena nilai dari masing-masing Conbrach's Alpha yang diperoleh lebih dari 0,6, yaitu nilai Conbrach's Alpha untuk kuesioner utility system sebesar 0,969 dan nilai Conbrach's Alpha untuk kuesioner metode EUCS sebesar 0,945.

Tabel 5. Hasil uji reliabilitas kuesioner

\begin{tabular}{|c|c|c|c|}
\hline Metode & $\begin{array}{c}\text { Conbrach's } \\
\text { Alpha }\end{array}$ & $\begin{array}{c}\text { N of } \\
\text { Items }\end{array}$ & Keterangan \\
\hline $\begin{array}{c}\text { Utility } \\
\text { System }\end{array}$ & 0,969 & 15 & Reliabel \\
\hline EUCS & 0,945 & 12 & Reliabel \\
\hline
\end{tabular}

\subsection{Karakteristik Responden}

Penelitian ini merupakan jenis penelitian kuantitatif dengan jumlah sampel berjumlah II0 responden. Adapun karakteristik responden yang terlibat disajikan pada gambar berikut:

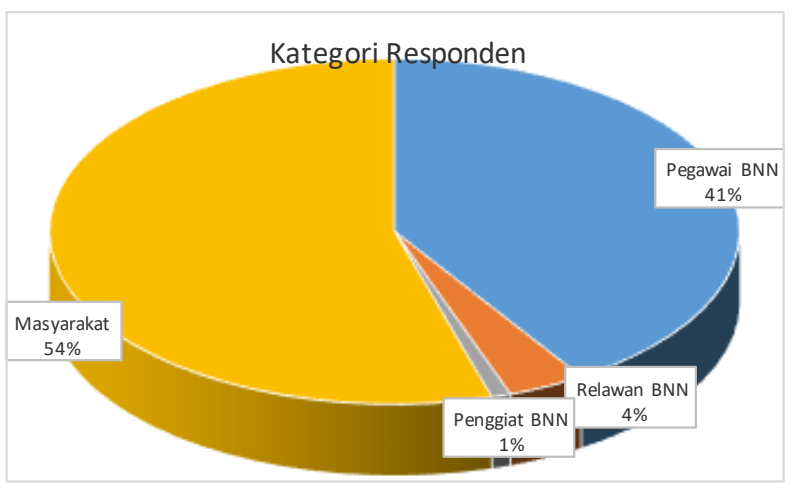

Gambar 3. Karakteristik responden berdasarkan kategori

Data responden berdasarkan kategori responden terdiri dari pegawai $\mathrm{BNN}$, relawan $\mathrm{BNN}$, penggiat $\mathrm{BNN}$ dan masyarakat. Berdasarkan gambar, diketahui mayoritas responden berdasarkan kategori responden adalah masyarkat sebanyak 60 responden atau sebesar $54 \%$, pegawai BNN sebanyak 45 responden atau sebesar $41 \%$, diikuti relawan BNN sebanyak 4 responden atau sebesar $4 \%$ dan minoritas adalah penggiat BNN sebanyak I responden atau sebesar $1 \%$.

3.3. Analisis Data Berdasarkan Pendekatan Utility System

Hasil analisis jawaban kuesioner untuk 15 item pernyataan dari 6 variabel berdasarkan pendekatan utility system disajikan dalam tabel sebagai berikut:

Tabel 6. Hasil analisis metode utility system

\begin{tabular}{cccc}
\hline Variabel & $\begin{array}{c}\text { Nilai } \\
\text { Deskriptif }\end{array}$ & $\begin{array}{c}\text { Interval } \\
\text { Indeks } \\
\mathbf{( \% )}\end{array}$ & Kategori \\
\hline Possesion & 3,83 & 76,55 & Baik \\
Goal & 3,92 & 78,36 & Baik \\
Place & 4,13 & 82,35 & Sangat Baik \\
Form & 3,79 & 75,88 & Baik \\
Time & 3,97 & 79,45 & Baik \\
Actualization & 3,96 & 79,27 & Baik \\
Rerata & $\mathbf{3 , 9 3}$ & $\mathbf{7 8 , 6 4}$ & Baik \\
\hline
\end{tabular}

Berdasarkan Tabel 6 diketahui bahwa rerata nilai deskriptif yang diperoleh untuk menilai efektivitas website berdasarkan pendekatan utility system adalah sebesar 3,93 dan interval indeksnya sebesar 78,64\% sehingga termasuk dalam kategori baik. Walaupun demikian, masih terdapat hal-hal yang perlu diperbaiki sesuai dengan interval indeks yang diperoleh setiap item pernyataan yang mewakili sebuah indikator.

Hasil analisis data kuesioner pada variabel possesion yang terdiri dari 2 (dua) item pernyataan, dapat dilihat pada gambar di bawah ini:

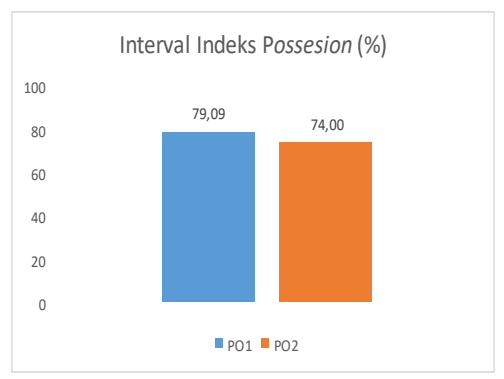

Gambar 4. Interval indeks variabel possession

Rerata interval indeks variabel possesion sebesar 76,55\%. Rerata interval indeks tersebut menunjukkan 
Wahida Purnamasari. Kajian Efektifitas Dan Kepuasan Pengguna Website Badan Narkotika 2021 Nasional Kota Kupang.

bahwa pernyataan output situs web BNN Kota Kupang memang seharusnya saya yang terima berada pada kategori baik dengan nilai interval indeks sebesar 79,09\%, sedangkan pernyataan output situs web BNN Kota Kupang sudah tepat sasaran berada pada kategori baik dengan nilai interval indeks sebesar $74,00 \%$, hal ini berarti bahwa mayoritas responden menilai informasi yang disajikan tidak mutlak tepat sasaran. Hal tersebut cukup lumrah karena mengingat mayoritas responden yang berasal dari kalangan masyarakat umum dari berbagai profesi pekerjaan, sehingga tidak semua informasi disajikan tepat sasaran.

Dari hasil analisis terhadap kedua item tersebut memperoleh perbedaan nilai yang cukup mencolok, walaupun rerata interval indeks untuk variabel possesioan berada pada kategori baik. Rerata interval indeks variabel possesion berada pada kategori baik yang berarti keluaran informasi situs web tersebut sudah memiliki tingkat kepemilikan yang baik dengan kebutuhan dari para pengunjung situs web. Walaupun demikian, secara teori dikatakan bahwa untuk memenuhi aspek possesion maka situs web harus memuat informasi tentang tujuan web untuk siapa, digunakan untuk membahas apa, dan dibuat untuk apa yang biasanya terkandung pada layanan about us/tentang kami/profil. Setelah diobservasi, ternyata pada situs web tidak memuat hal tersebut. Memang terdapat layanan profil tetapi hanya memuat informasi tentang sejarah, visi dan misi, tugas pokok dan fungsi, struktur organisasi dan kepala BNNK dari masa ke masa, sehingga hal ini menjadi catatan penting dari hasil evaluasi ini.

Hasil analisis data kuesioner pada variabel goal yang terdiri dari 3 (tiga) item pernyataan, disajikan pada gambar di bawah ini:

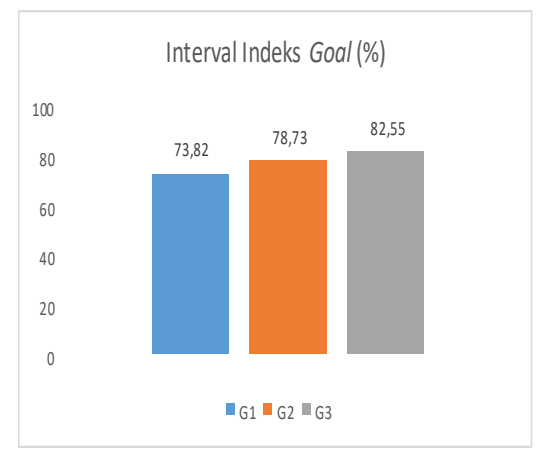

Gambar 5. Interval indeks variabel goal

Diketahui bahwa rerata interval indeks variabel goal sebesar 78,36\%. Rerata interval indeks tersebut menunjukkan bahwa pernyataan situs web BNN Kota Kupang memudahkan pekerjaan saya berada pada kategori baik dengan nilai interval indeks sebesar $73,82 \%$, pernyataan output situs web BNN Kota Kupang sesuai dengan kenyataan berada pada kategori baik dengan nilai interval indeks sebesar $78,73 \%$ sedangkan pernyataan kehadiran situs web BNN Kota Kupang bermanafaat bagi saya berada pada kategori sangat baik dengan nilai interval indeks sebesar $82,55 \%$. Dari hasil analisis terhadap ketiga item tersebut memperoleh perbedaan nilai yang cukup mencolok, walaupun rerata interval indeks untuk variabel goal berada pada kategori baik.

Secara teori, variabel goal terkait erat dengan tujuan dari pembuatan situs. situs web yang baik akan menjelaskan tujuan dari situs web tersebut dan dalam mencapai tujuannya harus memiliki reputasi yang baik yang berdampak pada akurasi informasi yang disajikan. Hal ini berarti bahwa, variabel goal berkaitan erat dengan variabel lainnya seperti variable possesion, dan variabel actualization. Sehingga wajar jika nilai rerata interval indeks yang diperoleh tidak memiliki perbedaan yang signifikan dengan variabel terkait.

Hal pokok dari variabel ini adalah pentingnya tujuan dari pembuatan situs web yang bukan hanya tertulis jelas tetapi juga harus relevan terhadap pengguna dengan akurasi yang baik dan disertai oleh lembaga penanggung jawab yang bereputasi.

Hasil analisis data kuesioner pada variabel place yang terdiri dari 3 (tiga) item pernyataan, disajikan pada gambar berikut:

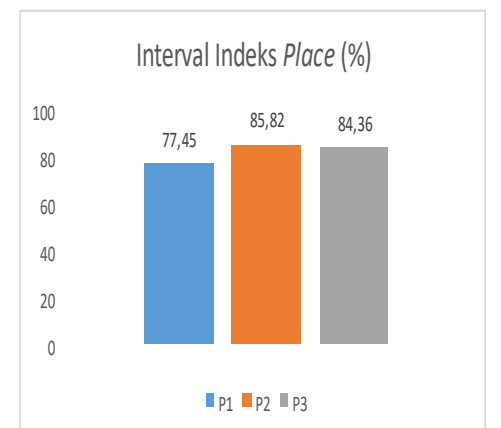

Gambar 6. Interval indeks variabel place

Berdasarkan gambar, diketahui bahwa aspek yang perlu diperhatikan pada variabel place adalah aspek PI dengan nilai interval indeks sebesar $77,45 \%$. Walaupun termasuk dalam kategori baik, akan tetapi isi pernyataannya yaitu output dari situs web BNN Kota Kupang didistribusikan dengan cepat ke pihak yang membutuhkannya memiliki nilai terendah maka perlu diperhatikan. Untuk pernyataan situs web BNN Kota Kupang dapat diakses dengan mudah berada pada kategori sangat baik dengan nilai interval indeks sebesar $85,82 \%$ sedangkan pernyataan informasi dari situs web BNN Kota Kupang dapat diakses oleh semua pihak yang membutuhkannya berada pada kategori sangat baik dengan nilai interval indeks sebesar $84,36 \%$.

Rerata interval indeks untuk variabel place berada pada kategori sangat baik. Walaupun rerata interval indeksnya berada pada kategori sangat baik, tetapi masih ada yang harus dilakukan evaluasi untuk mengetahui 
seberapa jauh informasi dapat tersebar atau didistribusi ke pengguna informasi.

Hasil analisis data kuesioner pada variabel form yang terdiri dari 3 (tiga) item pernyataan, disajikan pada gambar di bawah ini:

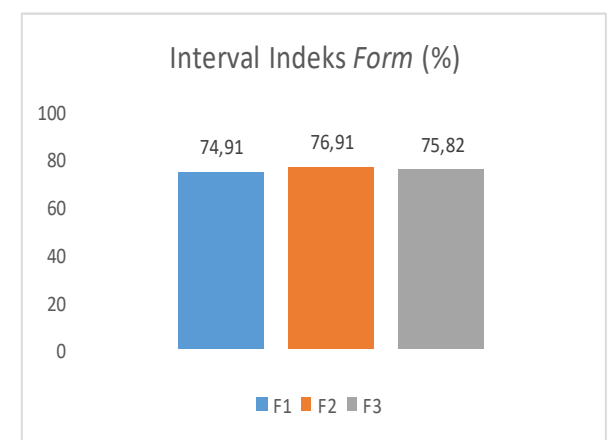

Gambar 7. Interval indeks variabel form

Variabel form merupakan variabel dengan nilai rerata interval indeks terendah yakni sebesar 75,88\% walaupun berada pada kategori baik. Secara teori variabel form digunakan untuk mengevaluasi apakah keluaran yang sudah dihasilkan disajikan dalam bentuk yang bermanfaat bagi pengguna sistem.

Rerata interval indeks tersebut menunjukkan bahwa pernyataan output dari situs web BNN Kota Kupang dapat dikonversi kebentuk file lain berada pada kategori baik dengan nilai interval indeks sebesar 74,91\%, untuk pernyataan output dari situs web BNN Kota Kupang dapat dikirimkan dengan mudah dalam bentuk file attachment (email) berada pada kategori baik dengan nilai interval indeks sebesar 76,91\% sedangkan pernyataan output situs web BNN Kota Kupang mudah disimpan dalam bentuk lain berada pada kategori baik dengan nilai interval indeks sebesar 75,82\%. Setelah dilakukan observasi terhadap situs web BNN Kota Kupang, hasil yang didapatkan adalah keluaran yang dihasilkan hanya dapat disimpan dalam bentuk webpage dan tidak bisa dikonversi kebentuk file yang lain, tetapi dapat dikirimkan dengan mudah ke bentuk file attachment (email) sehingga merupakan nilai interval indeks tertinggi pada aspek pernyataan ini.

Hasil analisis data kuesioner pada variabel time yang terdiri dari 2 (dua) item pernyataan, dapat dilihat pada gambar di bawah ini:

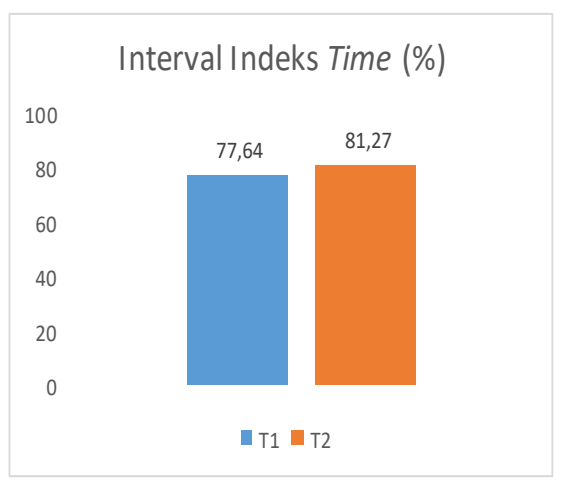

\section{Gambar 8. Interval indeks variabel time}

Diketahui bahwa rerata interval indeks variabel time sebesar $79,45 \%$. Rerata interval indeks tersebut menunjukkan bahwa pernyataan output yang dihasilkan tepat waktu berada pada kategori baik dengan nilai interval indeks sebesar $77,64 \%$ sedangkan pernyataan output dari situs web BNN Kota Kupang mudah diakses saat dibutuhkan berada pada kategori sangat baik dengan nilai interval indeks sebesar $81,27 \%$. Dari hasil analisis terhadap kedua item tersebut memperoleh perbedaan nilai yang cukup mencolok, walaupun rerata interval indeks untuk variabel time berada pada kategori baik.

Selanjutnya, hasil analisis data kuesioner pada variabel actualization yang terdiri dari 2 (dua) item pernyataan, dapat dilihat pada gambar berikut:

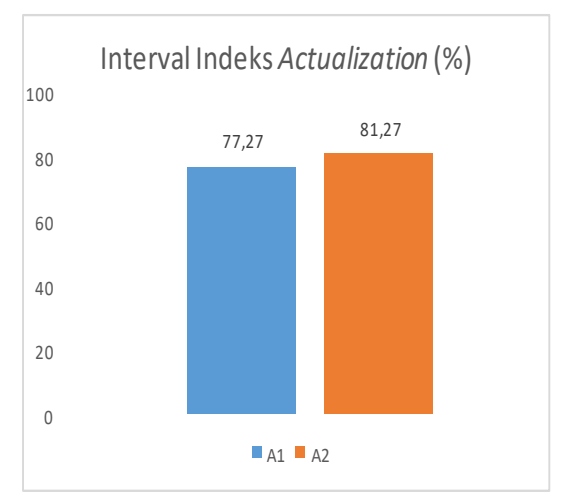

Gambar 9. Interval indeks variabel actualization

Adapun rerata interval indeks variabel actualization sebesar 79,27\%. Rerata interval indeks tersebut menunjukkan bahwa pernyataan konten situs web BNN Kota Kupang selalu diperbarui dengan informasi terkini berada pada kategori baik dengan nilai interval indeks sebesar $77,27 \%$ sedangkan pernyataan isi output dari situs web BNN Kota Kupang bermanfaat bagi saya berada pada kategori sangat baik dengan nilai interval indeks sebesar $81,27 \%$. Dari hasil analisis terhadap kedua item tersebut memperoleh perbedaan nilai yang cukup mencolok, walaupun rerata interval indeks untuk variabel actualization berada pada kategori baik.

Setelah dibandingkan melalui observasi diperoleh perbedaan hasil dengan analisis interval indeks. Untuk salah satu item pernyataan pada variabel actualization, yaitu pernyataan konten situs web BNN Kota Kupang selalu diperbarui dengan informasi terkini tidak terpenuhi, karena di situs web BNN Kota Kupang terakhir mengupadate berita pada tanggal I7 Maret 202I. Buktinya dapat dilihat pada gambar hasil tangkapan layar berikut: 
Wahida Purnamasari. Kajian Efektifitas Dan Kepuasan Pengguna Website Badan Narkotika 2021 Nasional Kota Kupang.

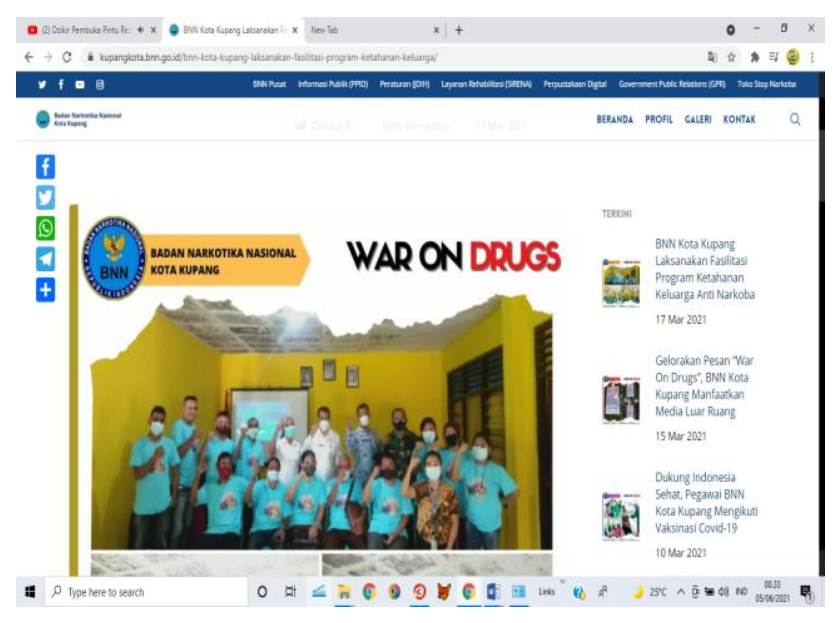

Gambar 10. Hasil tangkapan layar pada situs web

\subsection{Analisis Data Berdasarkan Metode End User} Computing Satisfaction (EUCS)

Analisis data kuesioner untuk 12 (dua belas) item pernyataan dari 5 (lima) variabel berdasarkan metode EUCS akan dibahas sebagai berikut:

Tabel 7. Hasil analisis metode EUCS

\begin{tabular}{|c|c|c|c|}
\hline NO & VARIABEL & $\begin{array}{c}\text { CAPAIAN } \\
\text { INDIKATOR } \\
(\%)\end{array}$ & KATEGORI \\
\hline 1 & Content & 78,23 & Tinggi \\
\hline 2 & Accuracy & 79,36 & Tinggi \\
\hline 3 & Format & 80,27 & Sangat Tinggi \\
\hline 4 & Timeliness & 77,18 & Tinggi \\
\hline 5 & Ease of Use & 81,09 & Sangat Tinggi \\
\hline \multicolumn{2}{|c|}{ RERATA } & $\mathbf{7 9 , 2 2}$ & Tinggi \\
\hline
\end{tabular}

Berdasarkan Tabel 7 diketahui bahwa urutan tertinggi sampai terendah capaian indikator masingmasing variabel adalah variabel format menempati urutan tertinggi pertama dengan capaian indikator sebesar $80,27 \%$. Tertinggi kedua ditempati variabel ease of use dengan capaian indikator sebesar $81,09 \%$. Variabel accuracy dengan capaian indikator sebesar 79,36\% menempati urutan tertinggi ketiga. Urutan capaian indikator sebesar $78,23 \%$. Urutan terendah terakhir atau paling rendah ditempati variabel timeliness dengan capaian indikator sebesar $77,18 \%$.

Rerata capaian indikator untuk metode EUCS sebesar 79,22\%. Berdasarkan kriteria tingkat kepuasan yang ditunjukkan pada Tabel 5, maka dapat disimpulkan bahwa tingkat kepuasan pengguna akhir tingkat kepuasan pengguna akhir memiliki tingkat kepuasan tinggi terhadap website BNN Kota Kupang.

Hasil analisis data kuesioner pada variabel content yang terdiri dari 4 (empat) item pernyataan, disajikan pada gambar di bawah ini:

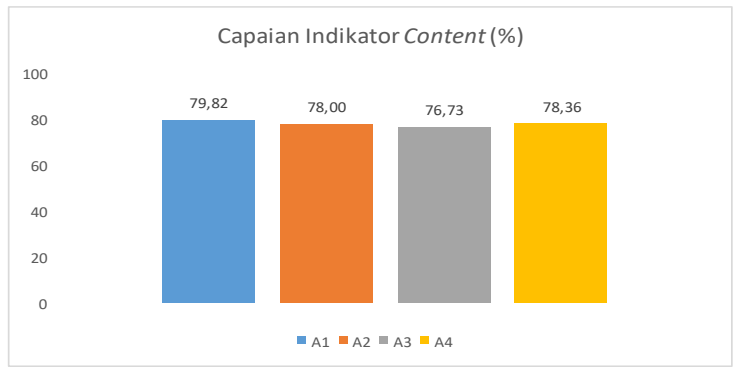

Gambar II. Capaian indikator variabel content

Diketahui bahwa rerata capaian indikator variabel content sebesar 78,23\%. Rerata capaian indikator tersebut menunjukkan bahwa pernyataan situs web BNN Kota Kupang memberikan informasi yang tepat sesuai yang saya butuhkan berada pada kategori tinggi dengan nilai capaian indikator sebesar $79,82 \%$. Untuk pernyataan konten informasi dari BNN Kota Kupang memenuhi kebutuhan saya berada pada kategori tinggi dengan nilai capaian indikator sebesar $78,00 \%$, dan untuk pernyataan situs web BNN Kota Kupang memberikan laporan yang persis sesuai kebutuhan saya berada pada kategori tinggi dengan nilai capaian indikator sebesar $76,73 \%$, serta pernyataan situs web BNN Kota Kupang memberikan informasi yang lengkap berada pada kategori tinggi dengan nilai capaian indikator sebesar $78,36 \%$. Nilai capaian indikator dari keempat item pernyataan pada variabel content tidak terlalu mencolok dan rerata capaian indikatornya berada pada kategori baik.

Rerata capaian indikatornya yang berada pada kategori tinggi, maka dapat disimpulkan bahwa pengguna memiliki tingkat kepuasan yang tinggi pada variabel content. Keadaan ini menunjukkan bahwa isi informasi dari website sudah sesuai dengan yang diharapkan pengguna, pengguna mendapatkan manfaat dengan adanya situs web BNN Kota Kupang. Walaupun berada pada kategori tinggi, ada hal yang perlu menjadi perhatian yaitu isi website bukan hanya berisi kegiatan yang dilakukan oleh BNN Kota Kupang, tetapi ada penambahan isi website berupa artikel tentang narkoba, jenis-jenis narkoba, bahaya penyalahgunaan narkoba. Sehingga isi dari website lebih sesuai dengan kebutuhan pengguna.

Hasil analisis data kuesioner pada variabel accuracy yang terdiri dari 2 (dua) item pernyataan, dapat dilihat pada gambar di bawah ini:

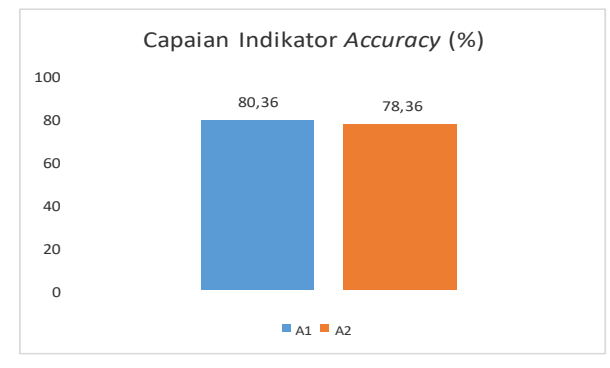




\section{Gambar 12. Capaian indikator variabel accuracy}

Berdasarkan gambar dapat diketahui bahwa rerata capaian indikator variabel accuracy sebesar 79,36\%. Rerata capaian indikator tersebut menunjukkan bahwa pernyataan situs web BNN Kota Kupang menghasilkan informasi yang akurat berada pada kategori sangat tinggi dengan nilai capaian indikator sebesar $80,36 \%$, setelah dibandingkan melalui hasil wawancara bahwa sebuah berita yang akan diposting melalui proses review dan editing, dan juga membutuhkan persetujuan penanggung jawab situs web untuk memposting berita. Sedangkan pernyataan saya puas dengan keakuratan informasi dari situs web BNN Kota Kupang berada pada kategori tinggi dengan nilai capaian indikator sebesar 78,36\%, setelah dibandingkan melalui hasil observasi didapatkan pada berita yang diposting tidak terdapat inisial nama siapa yang memposting berita tersebut. Mengakibatkan hasil capaian indikator untuk A2 berada dikategori tinggi berbanding dengan aspek Al yang berada pada kategori sangat tinggi.

Nilai capain indikator yang diperoleh oleh kedua item variabel accuracy tidak terlalu mencolok, tetapi ketika nilai capaian indikator dari kedua variabel tersebut dikonfersi sesuai dengan kategori capaian indikator maka terlihat mecolok, karena aspek AI berada pada kategori sangat baik sedangkan A2 berada pada kategori tinggi. Dan rerata capaian indikator variabelnya berada pada kategori tinggi.

Rerata capaian indikator variabel accuracy yang berada pada kategori tinggi, yang berarti informasi yang disajikan memiliki tingkat keakuratan yang tinggi, maka dapat disimpulkan bahwa pengguna memiliki tingkat kepuasan yang tinggi terhadap keakuratan informasi yang disajikan website BNN Kota Kupang.

Hasil analisis data kuesioner pada variabel format yang terdiri dari 2 (dua) item pernyataan, dapat dilihat pada gambar di bawah ini:

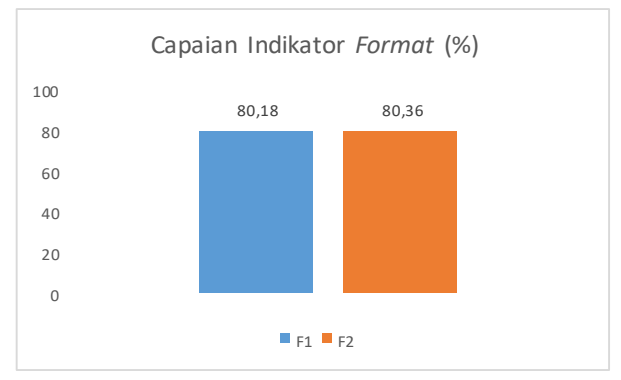

Gambar 13. Capaian indikator variabel format

Dari gambar 13 di atas dapat diketahui bahwa rerata capaian indikator variabel format sebesar $80,27 \%$. Rerata capaian indikator tersebut menunjukkan bahwa pernyataan output dari situs web BNN Kota Kupang disajikan dalam format yang bermanfaat berada pada kategori sangat tinggi dengan nilai capaian indikator sebesar $80,18 \%$ sedangkan pernyataan informasi dari situs web BNN Kota Kupang jelas berada pada kategori sangat tinggi dengan nilai capaian indikator sebesar $80,36 \%$. Dari hasil analisis terhadap kedua item tersebut nilai capaian indikator tidak terlalu mencolok dan rerata capaian indikatornya berada pada kategori sangat tinggi.

Hasil analisis data kuesioner pada variabel timeliness yang terdiri dari 2 (dua) item pernyataan, disajikan pada gambar berikut:

Capaian Indikator Timeliness (\%)

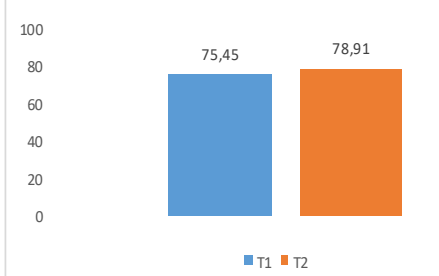

Gambar 14. Capaian indikator variabel timeliness

Adapun rerata capaian indikator variabel timeliness sebesar $77,18 \%$. Rerata capaian indikator tersebut menunjukkan bahwa pernyataan situs web BNN Kota Kupang tepat pada waktunya berada pada kategori tinggi dengan nilai interval indeks sebesar 75,45\% sedangkan pernyataan situs web BNN Kota Kupang menyajikan informasi terkini berada pada kategori tinggi dengan nilai interval indeks sebesar 78,91\%. Dari hasil analisis terhadap kedua item tersebut nilai capaian indikator tidak terlalu mencolok dan rerata capaian indikatornya berada pada kategori tinggi.

Pernyataan variabel timeliness (T2) situs web BNN Kota Kupang menyajikan informasi terkini sama dengan pernyataan pada variabel actualization (AI) konten situs web BNN Kota Kupang selalu diperbarui dengan informasi terkini, dimana setelah dibandingkan melalui observasi diperoleh perbedaan hasilnya yaitu pada situs web BNN Koa Kupang berita yang terakhir diposting pada tanggal 17 Maret 2021, sedangkan observasi dilakukan pada tanggal 04 Juni 2021.

Hasil analisis data kuesioner pada variabel ease of use yang terdiri dari 2 (dua) item pernyataan, disajikan pada gambar di bawah ini:

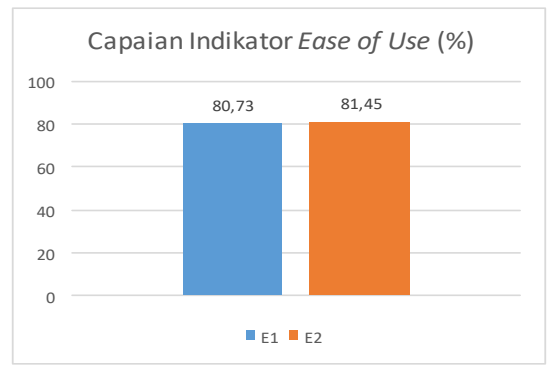

Gambar 15. Capaian indikator variabel ease of use

Rerata capaian indikator variabel ease of use sebesar $81,09 \%$. Rerata capaian indikator tersebut menunjukkan bahwa pernyataan situs web BNN Kota 
Wahida Purnamasari. Kajian Efektifitas Dan Kepuasan Pengguna Website Badan Narkotika 2021 Nasional Kota Kupang.

Kupang user friendly berada pada kategori sangat tinggi dengan nilai capaian indikator sebesar $80,73 \%$ sedangkan pernyataan situs web BNN Kota Kupang mudah digunakan berada pada kategori sangat tinggi dengan nilai capaian indikator sebesar $81,45 \%$. Dari hasil analisis terhadap kedua item tersebut nilai capaian indikator tidak terlalu mencolok dan rerata capaian indikatornya berada pada kategori sangat tinggi.

Rerata capaian indikator pada variabel ease of use merupakan rerata yang tertinggi dari semua variabel metode end user computing satisfaction. Ketika dilakukan observasi dengan situs web, bahwa situs web BNN Kota Kupang mudah digunakan dan link yang berada pada situs web tersebut semuanya terhubung.

3.5. Kesimpulan Hasil Analisis Dan Rekomendasi Perbaikan

Analisis terhadap hasil evaluasi dari kedua aspek memperoleh kesimpulan bahwa situs web BNN Kota Kupang belum sampai pada level top performance walaupun secara keseluruhan sudah baik. Hal itu dikarenakan oleh ditemukannya beberapa permasalahan minor yang tentunya wajib untuk diperbaiki agar meningkatkan kinerja dari situs web tersebut.

Rangkuman rekomendasi perbaikan yang disarankan kepada pihak yang berwewenang berdasarkan hasil analisis adalah sebagai berikut:

I. Menambah about us/tentang kami pada menu profile, dimana tentang kami menjelaskan informasi yang disajikan untuk siapa, membahasa tentang apa, apa tujuan dari pembuatan situs web tersebut.

2. Informasi/berita yang disajikan dalam situs web disertakan dengan siapa yang menulis berita tersebut sehingga berita tersebut lebih akurat dan terpercaya.

3. Tata letak dan desain website perlu diperhatikan sesuai kebutuhan pengguna dan disesuaikan juga dengan prinsip interaksi manusia dengan komputer.

4. Isi website bukan hanya berisi kegiatan yang telah dilaksanakan, tetapi ada penambahan isi website berupa artikel tentang narkoba, jenis-jenis narkoba, bahaya penyalahgunaan narkoba. Sehingga isi dari website lebih sesuai dengan kebutuhan pengguna.

5. Website tetap harus diperbaharui dengan berita terkini,sehingga berita yang disajikan tetap up to date.

6. Perlu adanya data jumlah pengguna yang mengunjungi website.

7. Meminimilisir penggunaan scrolling untuk menggulung halaman.

\section{SIMPULAN DAN SARAN}

Berdasarkan hasil analisis diperoleh rerata interval indeks dari 6 variabel pada metode utility system sebesar $78,68 \%$ yang dikategorikan dalam tingkat kelayakan baik. Hasil tersebut menunjukkan bahwa responden menilai website BNN Kota Kupang efektif sebagai media informasi. Sedangkan rerata capaian indikator dari 5 variabel metode EUCS menunjukkan tingkat kepuasan pengguna pada kategori tinggi dengan nilai rerata sebesar $77,22 \%$, yang berarti bahwa pengguna merasa puas menggunakan website BNN Kota Kupang. Hasil penelitian secara umum menunjukkan bahwa website BNN Kota Kupang dapat digunakan sebagai media informasi juga untuk membantu BNN Kota Kupang dalam menjalankan program kerjanya dengan efektif dan memuaskan.

Walaupun demikian, masih terdapat hal-hal yang perlu diperbaiki dan ditingkatkan. Oleh karena itu disarankan melakukan perbaikan sesuai dengan rekomendasi yang diberikan. Selain itu, perlu dilakukan evaluasi secara berkala dengan menggunakan metode/pendekatan lain agar website BNN Kota Kupang memiliki performa yang sangat baik dan dapat diandalkan.

\section{DAFTAR PUSTAKA}

Badan Narkotika Nasional. 2015. Peraturan Kepala Badan Narkotika Nasional Nomor 3 Tahun 2015 tentang Organisasi dan Tata Laksana Kerja BNN Propinsi dan BNNK/Kota. Presiden Republik Indonesia - Jakarta.

Badan Narkotika Nasional Kota Kupang. 2017. Laporan Kinerja Instansi Pemerintah BNN Kota Kupang Tahun 2017. Kepala Badan Narkotika Nasional Kota Kupang - Kupang.

Falahah dan Rijayana, I., 20II. Evaluasi Implementasi Sistem Informasi dengan Pendekatan Utility System (Studi Kasus Sistem E-Campus Universitas Widyatama).

Ghozali, I. 20I3. Aplikasi Analisis Multivariate dengan Program SPSS Edisi Ketujuh. Semarang (ID): Badan Penerbit Universitas Diponegoro.

Hair, J. F., Black, W. C., Babin, B. J., dan Anderson, R. E., 2010. Multivariate Data Analysys. Seventh Edition. New York (US): Pearson Prentice Hall.

Rosalina. 2017. Pengujian Kepuasan Sistem Informasi Menggunakan End User Computing Satisfaction [Skripsi]. Jakarta (ID): Sistem Informasi, UIN Syarif Hidayatullah Jakarta.

Simarmata, J. 2010. Rekayasa Perangkat Lunak. Yogyakarta (ID): Andi Offset.

Sugiyono. 2017. Metode Penelitian Kuantitatif, Kualitatif, dan R\&D. Bandung (ID): Alfabeta.

Tjiptabudi, F. M. H., S. S. Igon, R. Bernardino and A. T. Muharram, "Secure and Effective Reengineering Information System and Business Processes of Cross-Border Control between the Republic of Indonesia and the Republic Democratic of TimorLeste," 2018 6th International Conference on Cyber and IT Service Management (CITSM), 2018, Pp. I-7, doi: I0.II09/CITSM.2018.86743 I8.

Tjiptabudi, F.M.H., Bernardino, R. 2020. Indonesia Terrestrial Border Control Information System And Business Processes Alignment. International 
Jurnal Sains Komputer dan Teknologi Informasi Page

e-issn: 2655-7460. Volume 4 No.1, April 2021 $35-44$

Journal of Business Process Integration and Management, I0(I), pp.5 I-6I 